\title{
Pengembangan Media Peta Puzzle dengan Pendekatan Contextual Teaching and Learning (CTL) Untuk Meningkatkan Hasil Belajar
}

\author{
Agustianamas Ciputra, Yatim Riyanto, Suhanadji \\ Universitas Negeri Surabaya, Jl. Lidah Wetan, Lidah Wetan, Kec. Lakarsantri, Kota Surabaya \\ Jawa Timur, 60213 \\ Correspondence Email: agustianamas.18027@mhs.unesa.ac.id
}

\begin{abstract}
Abstrak
Tujuan dari penelitian ini adalah untuk mendeskripsikan tingkat kelayakan media dan keefektifan dalam penggunaan media peta puzzle berbasis adobe flash dengan pendekatan contextual teaching and learning (CTL) untuk meningkatkan hasil belajar IPS kelas IV di SD. Jenis penelitian yang pilih pada penelitian ini adalah penelitian dan pengembangan (R\&D) dari Borg and Gall. Penelitian dilaksanakan pada tahun ajaran 2019/2020 dengan subjek penelitian berjumlah 20 siswa. Kelayakan dihasilkan dari hasil validasi yang dilakukan oleh para ahli. Hasil kelayakan media mendapatkan persentase $86 \%$ sedangkan kelayakan materi mendapatkan prosentase $85 \%$ Media peta puzzle berbasis adobe flash memperoleh kelayakan yang cukup tinggi dan efektif dibuktikan dengan hasil belajar yang dihitung menggunakan uji t menunjukkan bahwa table $(4,28)$ lebih besar dari thitung $(2,093)$. Penerapan media media peta puzzle berbasis adobe flash juga memperoleh tanggapan yang sangat baik dari guru kelas yaitu sebesar 90\% dan peserta didik sebesar $89 \%$. Dapat disimpulkan bahwa media peta puzzle berbasis adobe flash dengan pendekatan contextual teaching and learning (CTL) layak dan efektif untuk meningkatkan hasil belajar mata pelajaran IPS di kelas IV Sekolah Dasar.
\end{abstract}

\section{Kata Kunci:}

Media Peta Puzzle Berbasis Adobe Flash; Pendekatan Contextual Teaching And Learning (CTL); Hasil Belajar

\begin{abstract}
The purpose of this study is to describe the level of media feasibility and effectiveness in the use of adobe flashbased puzzle map media with a contextual teaching and learning (CTL) approach to improve social studies learning outcomes for class IV in elementary school. The type of research used is research and development $(R n D)$ from Borg and Gall. The study was conducted in the 2019/2020 school year with a total of 20 research subjects. Eligibility results from the results of validation carried out by experts. The results of the feasibility of the media to get $86 \%$ process while the feasibility of the material to get a percentage of $85 \%$ media puzzle map adobe flash obtain a high enough feasibility and effective proven by learning outcomes calculated using t test shows that $t_{\text {table }}(4.28)$ is greater than ${ }^{t}$ count $(2,093)$. The application of adobe flash-based puzzle media media also received a very good response from the class teacher at $90 \%$ and students at $89 \%$. It can be concluded that the adobe flash-based puzzle map media with contextual teaching and learning (CTL) approach is feasible and effective to improve the learning outcomes of social studies subjects in grade IV elementary schools.
\end{abstract}

Keywords:

Media Map Puzzle Based on Adobe Flash; Contextual Teaching And Learning (CTL); Learning Outcomes

1. Pendahuluan

Indonesia saat ini menerapkan

kurikulum baru dengan menyesuaikan perkembangan zaman. Kurikulum baru tersebut ialah Kurikulum 2013 yang diterapkan di Indonesia ini berbasis 
karakter dimana akan membentuk pribadi yang beriman, berakhlak baik dan bermartabat. Banyak perilaku yang menyimpang dari segi moral, sosial KKN dan sebagainya merupakan faktor dan alasan mengapa kurikulum 2013 diterapkan di Indonesia. Proses pembelajaran kritis, interaktif dan aktif, berbasis diskusi atau kelompok, student centered serta proses pembelajaran yang berbasis teknologi informasi merupakan karakteristik yang dikembangkan dalam Kurikulum 2013.

Tujuan dari pelaksanaan kurikulum 2013 di Indonesia antara lain meningkatkan keterampilan, peserta didik dituntut menguasai ranah afektif, psikomotorik dan afektif, meningkatkan keimanan, kreativitas dan keaktifan serta mampu berkontribusi untuk bangsa dan negara. Proses pembelajaran dalam Kurikulum 2013 menuntut peserta didik untuk mengembangkan empat ranah yang meliputi spiritual, afektif, psikomotorik dan kognitif. Proses pembelajaran di kelas, guru berperan sebagai faktor utama tercapainya tujuan kurikulum 2013. Peran guru sangatlah penting agar mutu pendidikan di Indonesia dapat berkembang dan meningkat. Pembelajaran yang diharapkan berjalan secara maksimal harus diimbangi dengan pembaruan berupa media atau pendekatan pembelajaran. Kebutuhan dan karakteristik yang berbeda- beda dari peserta didik maka dari itu guru diwajibkan untuk menerapkan media ataupun model yang sesuai.

Guru dipermudah dalam memilih media inovatif dan alat belajar dengan adanya perkembangan ilmu pengetahuan dan teknologi informasi. Kegiatan belajar di

1 Hariyanto dan Suyono. 2011. Belajar dan Pembelajaran. Bandung: Remaja Rosdakarya kelas diwajibkan untuk menerapkan media inovatif guna mendukung proses pembelajaran. Media inovatif tersebut digunakan untuk peserta didik dalam memenuhi kebutuhan di kelas dan mempermudah dalam memahami materi. pembelajaran. Peningkatan motivasi dan semangat peserta

Perkembangan teknologi ini mampu mempengaruhi proses pembelajaran, materi ajar dan cara penyajiannya di SD. Di Jenjang Sekolah Dasar, peserta didik dinilai menyukai proses pembelajaran dengan penerapan menggunakan permainan atau game disertai dengan gambar animasi yang menarik dan banyak warna. Permainan puzzle ini adalah media edukatif yang dinilai mampu meningkatkan daya ingat peserta didik. Permainan puzzle mempunyai manfaat yang dapat memudahkan dalam mengingat dan paham materi yang berisi banyak bentuk dan warna yang menarik dibandingkan hanya disuguhkan dengan tulisan saja. Menurut teori perkembangan jean piaget dalam tahap operasional konkret, peserta didik pada usia 6-12 tahun menyukai kegiatan belajar dengan memanfaatkan banyak media inovatif Guru dalam proses pembelajaran ini memberikan peserta didik suatu peristiwa nyata ataupun benda oleh guru dan kemudian akan diberikan peluang dalam penyelesaian masalahnya secara berkelompok dan berdiskusi. ${ }^{1}$

Salah satu mata pembelajaran yang dinilai membosankan dan sulit dipahami antara lain mata pelajaran IPS. Oleh karena itu, guru diwajibkan untuk memanfaatkan ragam dari media dan pendekatan pembelajaran. IPS merupakan salah satu 
mata pelajaran yang mengajarkan kehidupan sosial manusia dengan berlandasan dari ilmu-ilmu sosial. IPS ini memiliki peran penting, yaitu dijadikan pedoman oleh peserta didik dalam mengembangkan

keterampilan, sikap dan pengetahuan, sehingga mampu berperan aktif dan berkontribusi untuk bangsa dan negara. ${ }^{2}$

Penelitian dilaksanakan pada tanggal tanggal 22 November dan 21 Januari 2020 di SDN Tanjung Kediri. Peneliti melakukan observasi dan wawancara kemudian menemukan dan menganalisis permasalahan yang ada di kelas IV. ${ }^{3}$ Permasalahan yang ada meliputi jarang diterapkannya media inovatif untuk mata pelajaran IPS dan tidak adanya pendekatan pembelajaran yang membantu peserta didik dalam mempermudah memahami materi Masalah selanjutnya terlihat saat guru menerangkan materi ajar banyak peserta didik yang hanya menulis dan membaca saja dikarenakan guru tidak memfasilitasi media yang sesuai dengan kebutuhan peserta didik. Alasan utama mengapa guru kelas jarang menerapkan media adalah minimnya sarana dan prasarana serta keterbatasan waktu. Hal tersebut juga mengakibatkan banyaknya peserta didik mendapatkan nilai dibawah KKM dan rendahnya hasil nilai rata-rata kelas.

Berdasarkan masalah yang dijelaskan diatas, perlu adanya perbaikan dalam kegiatan belajar mengajar. Agar peserta didik terlibat secara langsung dalam kegiatan belajar di kelas, maka dianjurkan

\footnotetext{
2 Susanto, Ahmad. 2013. Teori Belajar dan Pembelajaran di Sekolah Dasar. Jakarta: Kencana ${ }^{3}$ Observasi awal januari 2020 guru kelas IV SDN tanjung Kediri.
}

untuk menerapkan media belajar yang beragam. Dengan adanya proses pembelajaran tersebut, mampu menumbuhkan motivasi belajar dan keaktifan dari peserta didik, serta peserta didik akan dimudahkan dalam mencerna materi yang disampaikan. Media yang dinilai mampu menyelesaikan masalah yang ada di kelas IV adalah dengan menerapkan media peta puzzle berbasis adobe flash dengan pendekatan contextual teaching and learning (CTL) .

Karakteristik dari media yang dikembangkan ini antara lain peserta didik akan diajak bermain sambil belajar. Penggunaan teknik bermain inilah peserta didik akan asyik bermain sampai tidak sadar jika mereka sedang melangsungkan proses pembelajaran. Peta puzzle berbasis adobe flash ini dipilih karena cocok dengan kebutuhan dan kriteria peserta didik. Peserta didik dilibatkan secara langsung dalam proses pembelajaran misal dalam menyelesaikan proyek atau masalah secara berkelompok dan menggali materi. Bermain mempunyai karakteristik untuk meningkatkan rasa senang, kepuasan diri dan merupakan salah satu yang dibutuhkan seseorang. ${ }^{4}$

Jamil (2012:20) mengatakan puzzle adalah susunan dari beberapa pecahan gambar yang dapat dijadikan satu gambar yang komplit. Kelebihan dari puzzle sendiri adalah peserta didik dapat mengembangkan berbagai keterampilan meliputi keterampilan kognitif, keterampilan sosial, keterampilan motorik halus keterampilan dalam berkonsentrasi

\footnotetext{
${ }^{4}$ Andang, Ismail. 2009. Education Games Menjadi Cerdas dan Ceria Dengan Permainan Edukatif. Yogyakarta: Pilar Media
} 
dan menalar serta keterampilan dalam melatih kesabaran. Sedangkan pengertian peta puzzle adalah media yang dibuat guna untuk mempermudah guru dalam menjelaskan materi di desain dengan aplikasi populer yakni adobe flash dan visualisasinya dapat ditampilkan di layar LCD agar peserta didik dapat melihat dan memahami secara jelas.

Peta puzzle didesain dengan menarik, jelas dan mudah sehingga materi akan tersampaikan ke peserta didik. Isi yang terdapat pada media peta puzzle antara lain games, materi dan quiz. Teknik dari media ini antara lain guru mengajak peserta didik untuk bermain menyusun potonganpotongan gambar yang terdapat pada layar kemudian menyusun menjadi satu gambar dengan bantuan mouse. Teknik permainan ini mengajak peserta didik untuk bekerjasama dan berdiskusi serta menggali, menemukan informasi- informasi penting yang berkaitan dengan tempat menarik di lingkungannya.

Salah satu perangkat lunak yang dimanfaatkan oleh banyak orang adalah aplikasi adobe flash. Dalam dunia pendidikan banyak guru dan profesional yang telah memanfaatkan salah satu software populer ini untuk membuat desain media yang menarik dan inovatif serta mampu mengerjakan proyek animasi, game, presentasi dan sebagainya. Adobe Flash merupakan software yang memiliki banyak manfaat karena dapat membuat berbagai hal mengenai multimedia. ${ }^{5}$

Pendekatan yang dinilai mampu menuntut peserta didik kelas IV di SDN Tanjung untuk menghubungkan materi

5 Pranowo, G. 2011. Kreasi Animasi Interaktif Dengan Actionscript 3.0 pada Adobe Flash CS5. Yogyakarta: Andi dengan kehidupan dan kondisi nyata adalah pendekatan contextual teaching and learning (CTL). CTL adalah pendekatan atau solusi yang dimanfaatkan oleh guru dalam mengajak peserta didik untuk menghubungkan dan menciptakan materi ke dalam kehidupan bermasyarakat ${ }^{6}$

Karakteristik yang terdapat dalam IPS ialah berhubungan dengan kehidupan sosial mengenai kehidupan manusia dalam sehari- hari dilingkungan. Materi yang banyak mengandung hafalan dinilai menjenuhkan dan problematis oleh peserta didik. Maka dari itu untuk menyelesaikan masalah yang ada di kelas diperlukan media konkrit yang disesuaikan dengan kebutuhan peserta didik. Media itu adalah media peta puzzle berbasis adobe flash dengan pendekatan contextual teaching and learning (CTL). Penggunaan media peta puzzle dinilai mampu memberikan pengalaman bermakna dan nyata serta peserta didik dapat mengembangkan keterampilan, keaktifan dan kerjasama antar teman.

Berdasarkan latar belakang masalah yang telah diuraikan, maka untuk memperbaiki dan menyelesaikan permasalahan penulis memilih judul yakni "Pengembangan Media Peta Puzzle berbasis Adobe Flash dengan Pendekatan Contextual Teaching and Learning (CTL) untuk Meningkatkan Hasil Belajar IPS Kelas IV di SD".

\section{Metode Penelitian}

Penelitian ini bertujuan untuk mendeskripsikan tingkat kelayakan dan keefektifan media yaitu media peta puzzle

\footnotetext{
${ }^{6}$ Suprijono, agus. 2012. Cooperative Learning Teori \& Aplikasi Pakem. Yogyakarta Pustaka Pelajar
} 
berbasis adobe flash dengan pendekatan contextual teaching and learning (CTL) untuk meningkatkan hasil belajar IPS kelas IV di SD. Penelitian dan pengembangan (R\&D) Borg dan Gall merupakan Jenis penelitian yang dipilih dalam penelitian ini. Penelitian dilaksanakan pada semester genap tahun ajaran 2019/2020 dengan subjek penelitian berjumlah 20 siswa.

Jenis penelitian yang dipilih (R\&D) Borg dan Gall bertujuan untuk mengembangkan suatu produk dan hasilnya layak serta dapat dipertanggungjawabkan sesuai yang terdapat dalam langkah- langkahnya. Terdapat 10 langkah dalam penelitian (R\&D) Borg dan Gall, namun karena keterbatasan waktu dan biaya maka penelitian ini hanya sampai pada langkah ke 9 yakni revisi produk final.

Dalam tahapan penelitian (R\&D) Borg dan Gall media yang dikembangkan diharuskan untuk diuji terlebih dahulu kepada ahli validasi meliputi validasi media dan validasi materi. Selanjutnya dilakukan uji coba terbatas dengan melibatkan 10 peserta didik. Setiap peserta didik mengisi lembar angket mengenai proses pembelajaran setelah mengoperasikan permainan puzzle. Selanjutnya hasil uji coba terbatas ini dianalisis untuk dijadikan dasar untuk melakukan perbaikan pada media. Setelah dilakukan perbaikan, uji coba dilakukan kembali dengan skala besar yakni 20 peserta didik. Peserta didik juga diberi tes hasil belajar guna mengetahui keefektifan media tersebut. Guru kelas juga memberikan tanggapan dengan mengisi lembar angket setelah mengikuti proses pembelajaran secara langsung.

Tes hasil belajar. observasi, wawancara, dan lembar angket merupakan instrumen yang dimanfaatkan oleh peneliti untuk mengumpulkan data pada penelitian pengembangan ini.

Selanjutnya data yang telah dihasilkan dengan lembar validasi nanti akan dianalisis kelayakan dengan menggunakan rumus sebagai berikut:

$\mathrm{p}=\quad \frac{\sum x}{\sum x i} x 100 \%$

\section{Keterangan:}

$\mathrm{P} \quad=$ Kelayakan

$\sum_{X} \quad=$ Jumlah Jawaban tertinggi

$\sum_{X i}=$ Jumlah jawaban Penilaian

Suatu produk dikatakan layak apabila memenuhi tingkat kelayakan berdasarkan prosentase dibawah ini:

Tabel 1. Kualifikasi Tingkat Kelayakan Berdasarkan Prosentase

\begin{tabular}{ccc}
\hline Prosentase $(\%)$ & Kualifikasi & Kriteria Kelayakan \\
\hline $84 \%<$ skor $\leq 100 \%$ & Sangat Valid & Tidak Revisi \\
$68 \%<$ skor $\leq 84 \%$ & Valid & Tidak Revisi \\
$52 \%<$ skor $\leq 68 \%$ & Cukup Valid & Perlu Revisi \\
$36 \%<$ skor $\leq 52 \%$ & Kurang Valid & Revisi \\
$\mathbf{2 0} \%<$ skor $\leq 36 \%$ & Sangat Kurang Valid & Revisi \\
\hline
\end{tabular}

Selanjutnya keefektifan dari media yang dikembangkan dapat diketahui dari hasil tes belajar siswa. Hasil tes tersebut selanjutnya dianalisis dengan memanfaatkan rumus one group pretest-posttest design: 


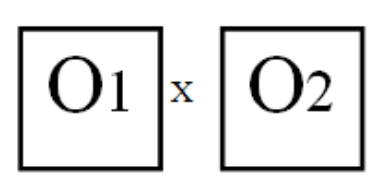

Gambar 1. Desain One Group Pretest-Posttest

\section{Keterangan:}

X : Pembelajaran menggunakan media pembelajaran peta puzzle berbasis adobe flash

O1 : Tes before treatment atau sebelum peserta didik diberi media pembelajaran

O2 : Tes after treatment atau sesudah peserta didik diberi media pembelajaran

Pengumpulan data yang adobe flash berbasis CTL terhadap hasil memanfaatkan pre-test dan post- test belajar.

bertujuan guna untuk mengetahui Selanjutnya rumus yang digunakan keefektifan media peta puzzle berbasis untuk uji t dengan menggunakan tingkat kemaknaan adalah:

$$
\mathrm{t}=\frac{D}{\frac{\sqrt{d^{2}}}{n[n-1)}} \frac{D}{\frac{\sqrt{d^{2}}}{n(n-1)} \frac{\sqrt{d^{2}}}{n(n-1)}}
$$

\section{Keterangan:}

$$
\begin{array}{ll}
\mathrm{t} & =\text { Uji } \mathrm{t} \\
\mathrm{D} & =\text { Different }\left(\mathrm{X}_{2}-\mathrm{X}_{1}\right) \\
\mathrm{d}^{2} & =\text { variasi } \\
\mathrm{N} & =\text { jumlah subjek/sampel }
\end{array}
$$

\section{Hasil dan Pembahasan}

Proses penelitian ini dilakukan sesuai tahapan penelitian dan pengembangan (R\&D) Borg and Gall. Berikut merupakan proses penelitian dalam pengembangan secara rinci:

3.1 Tahap Potensi dan Masalah: Tahap pertama yang dilakukan peneliti adalah menelusuri masalah serta menemukan potensi yang dapat dijadikan solusi terhadap permasalahan tersebut. Selain itu, peneliti juga mengamati secara langsung kegiatan pembelajaran dan melakukan wawancara pada guru maupun peserta didik. Guru dan salah satu peserta didik mendapatkan 7 pertanyaan yang telah disesuaikan dengan pedoman wawancara. Berdasarkan wawancara tersebut dapat disimpulkan bahwa masalah di kelas IV SD Tanjung yaitu minimnya penerapan media yang bervariasi dan pendekatan pembelajaran. Menurut guru kelas sebagai narasumber, yang menyebabkan minimnya penggunaan adalah faktor keterbatasan biaya dan waktu serta fasilitas yang memadai di sekolah tersebut. Sedangkan menurut salah satu peserta 
didik, menginginkan proses pembelajaran dengan penerapan media agar lebih bersemangat dan antusias.

3.2 Tahap Pengumpulan Data: Materi yang akan diajarkan sebelumnya harus dilakukan pengumpulan data berupa mencari materi yang sesuai dengan media tersebut. Materi tersebut terdapat pada tema 8 subtema 1 pembelajaran 4 dengan mata pelajaran Ilmu Pengetahuan Sosial. Pengumpulan data mengenai materi disajikan pada tabel dibawah ini:

Tabel 2. Tabel Pemetaan Kompetensi Dasar

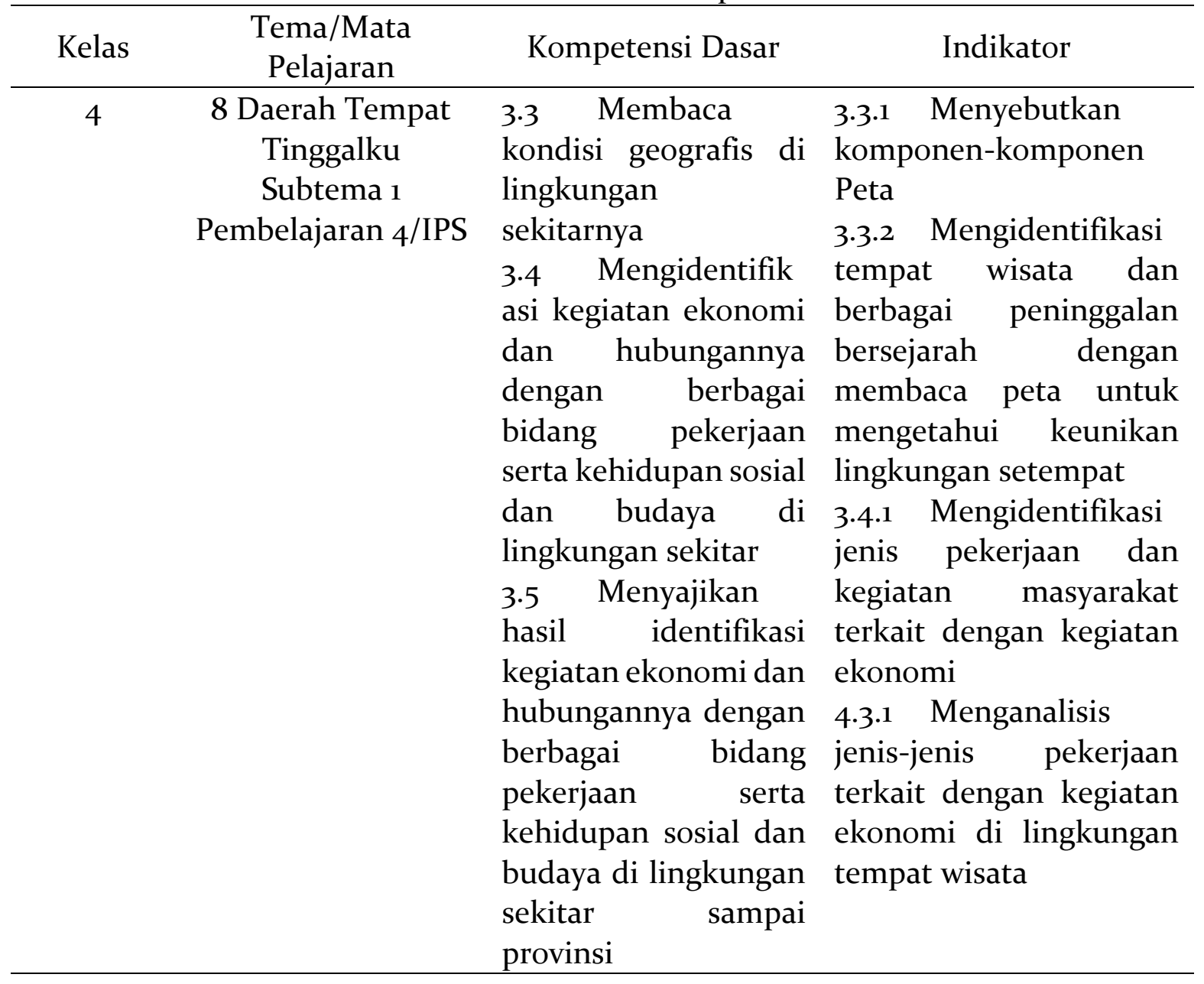

3.3 Tahap Desain Produk: Adobe flash CS6 dikhususkan untuk materi IPS dalam tema 8 subtema 1 pembelajaran 4. Media ini dikhususkan bagi peserta didik kelas IV, karena dinilai cocok. Pendekatan yang cocok untuk diterapkan pada media ini adalah pendekatan CTL. Aplikasi ini didesain dengan semenarik mungkin dan terdapat banyak warna dan tulisan yang disesuaikan dengan peserta didik. Pengoprasian pada aplikasi ini dibuat sangat mudah sehingga peserta didik dan guru tidak kesulitan. Berikut merupakan penyajian gambar yang 
telah pengembang buat dari desain media:

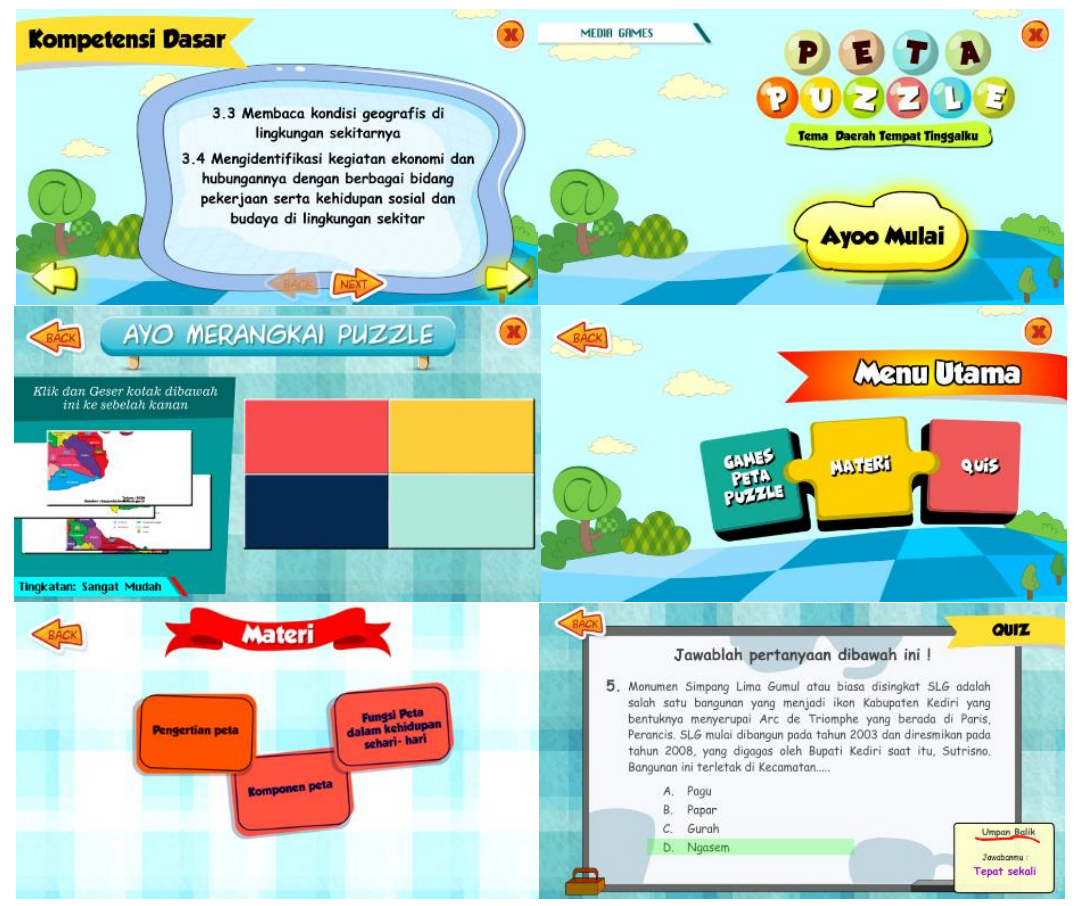

Gambar 2. Desain Media

3.4 Tahap Validasi Desain: Sebelum diujicobakan kepada peserta didik media dan materi yang telah dipersiapkan harus divalidasi terlebih dahulu.. Adapun hasil validasi dapat dilihat dibawah ini:

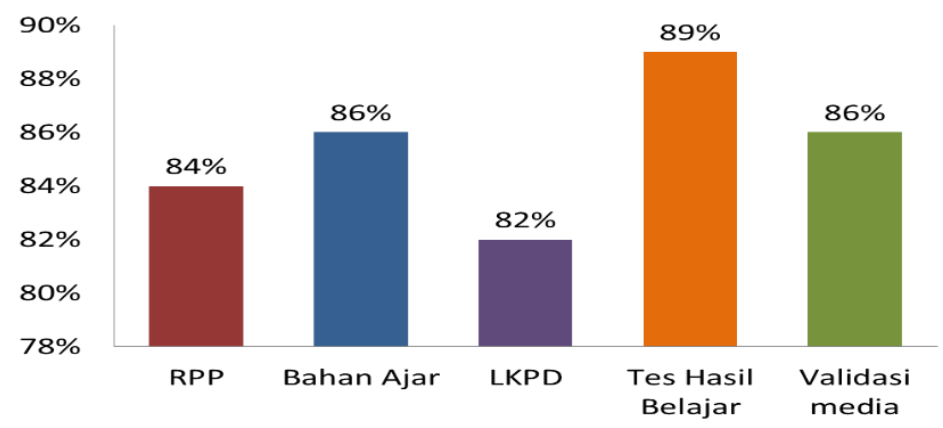

Gambar 3. Hasil Tahap Validasi Desain

3.5 Tahap Perbaikan Desain: Tahap selanjutnya dimana ahli media memberikan saran dan masukan terhadap desain media. Hal tersebut sangat perlu dan harus diperhatikan oleh peneliti. Dengan adanya perbaikan desain akan menghasilkan suatu media yang layak digunakan sebelum tahapan uji coba.

3.6 Tahap Uji Coba Produk: Selanjutnya adalah tahap tahap uji coba produk. Pertama peneliti memanfaatkan pada skala terbatas yang dilakukan oleh 10 peserta didik kelas IV dan kemudian 
dibagi menjadi 2 kelompok secara heterogen. Jika telah selesai dalam pengoperasian media, maka tiap peserta didik akan mengisi lembar angket untuk memberikan tanggapan. Hasil penilaian yang didapatkan akan dimanfaatkan untuk mengukur kelayakan media yang telah dikembangkan. Kemudian semua data yang telah terkumpul akan dihitung dengan menggunakan rumus dibawah ini:

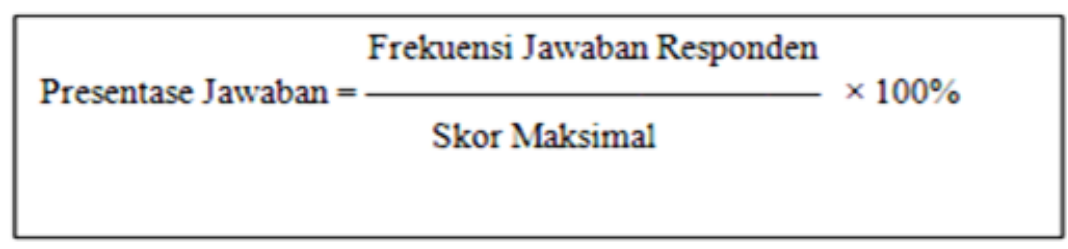

Gambar 4. Rumus Penilaian uji coba produk

Dari 15 pertanyaan yang telah diisi oleh peserta didik dan telah dihitung menggunakan rumus diketahui bahwa media peta puzzle berbasis adobe flash dengan pendekatan CTL mendapatkan kelayakan sebesar $88 \%$ dengan kriteria sangat layak.

3.7 Tahap Revisi Produk: Tahap selanjutnya, peneliti memperhatikan masukan mengenai produk yang telah dikembangkan dari guru kelas. Guru kelas dalam uji coba produk terbatas mendampingi peneliti dalam kegiatan belajar. Guru kelas juga mengamati kemudian memberikan suatu tanggapan dan saran apa saja yang harus diperbaiki mengenai media dan pendekatan yang telah digunakan di kelas tersebut. Dengan adanya masukan tersebut, memotivasi dan membantu peneliti demi memperbaiki media tersebut. Selain itu, guru kelas juga diberikan lembaran angket dengan
19 pertanyaan untuk diisi dengan hasil persentase sebesar $90 \%$

3.8 Tahap Uji Coba Pemakaian: Selanjutnya adalah tahap uji coba pemakaian dimana uji coba tersebut memanfaatkan skala besar. Penelitian ini melakukan uji coba dengan peserta didik berjumlah 20 yang kemudian dibagi menjadi 4 kelompok . Setiap kelompok dibagi secara heterogen masing- masing terdapat 5 peserta didik. Kemudian setiap peserta didik diberi kesempatan untuk mencoba dan mengaplikasikan media peta puzzle secara bergantian. Jika telah selesai dalam pengoperasian media, untuk mengetahui respon ataupun tanggapan penggunaan media, peserta didik diminta oleh peneliti untuk mengisi lembar angket.

Semua data yang telah terkumpul kemudian akan dihitung dengan menggunakan rumus dibawah ini:

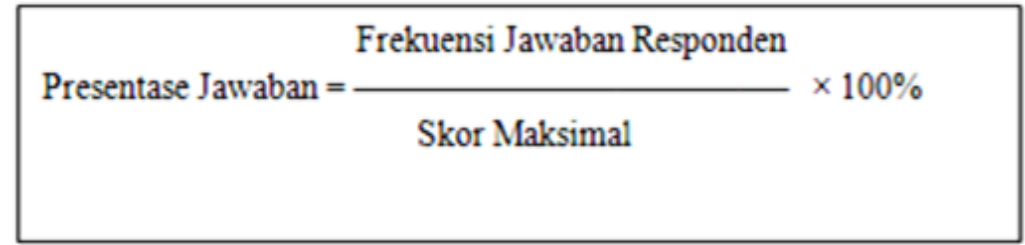

Gambar 4. Rumus Penilaian uji coba pemakaian 
Hasil yang telah dianalisis dan dihitung menggunakan rumus tersebut, dapat disimpulkan bahwa pada tahap uji coba skala besar media peta puzzle berbasis adobe flash dengan pendekatan CTL memiliki kelayakan sebesar $89 \%$.

3.9 Tahap Revisi Produk Final: Penelitian pengembangan diharuskan mendapatkan produk yang memiliki tingkat kelayakan dan keefektifan yang tinggi. Maka dari itu dilakukanlah tahap revisi produk. Dengan adanya saran dari ahli validasi dan guru kelas sangat memotivasi dan membantu peneliti untuk memperbaiki dan mengembangkan media yang lebih baik lagi. Akan tetapi hasil yang telah dianalisis dan dihitung dapat disimpulkan bahwa media peta puzzle berbasis adobe flash dengan pendekatan CTL memiliki kelayakan dan keefektifan yang tinggi untuk diterapkan di kelas IV.

Keefektifan media yang dikembangkan dapat dilihat dari hasil belajar peserta didik dengan menggunakan tes pretest dan posttest. Soal yang dibuat peneliti berjumlah 10 pilihan ganda dan 5 berbentuk uraian. Sebelum diujicobakan ke peserta didik tes hasil belajar juga dilakukan validasi ke ahli isi materi. Hasil belajar yang telah dihasilkan peserta didik kemudian dihitung menggunakan rumus desain one group pretest-posttest. Maka disimpulkan bahwa rata- rata nilai pretest mendapatkan nilai 59,4 dan nilai posttest mendapat nilai 88,5 . Dengan demikian disimpulkan bahwa hasil belajar peserta didik di kelas IV mengalami peningkatan secara signifikan.

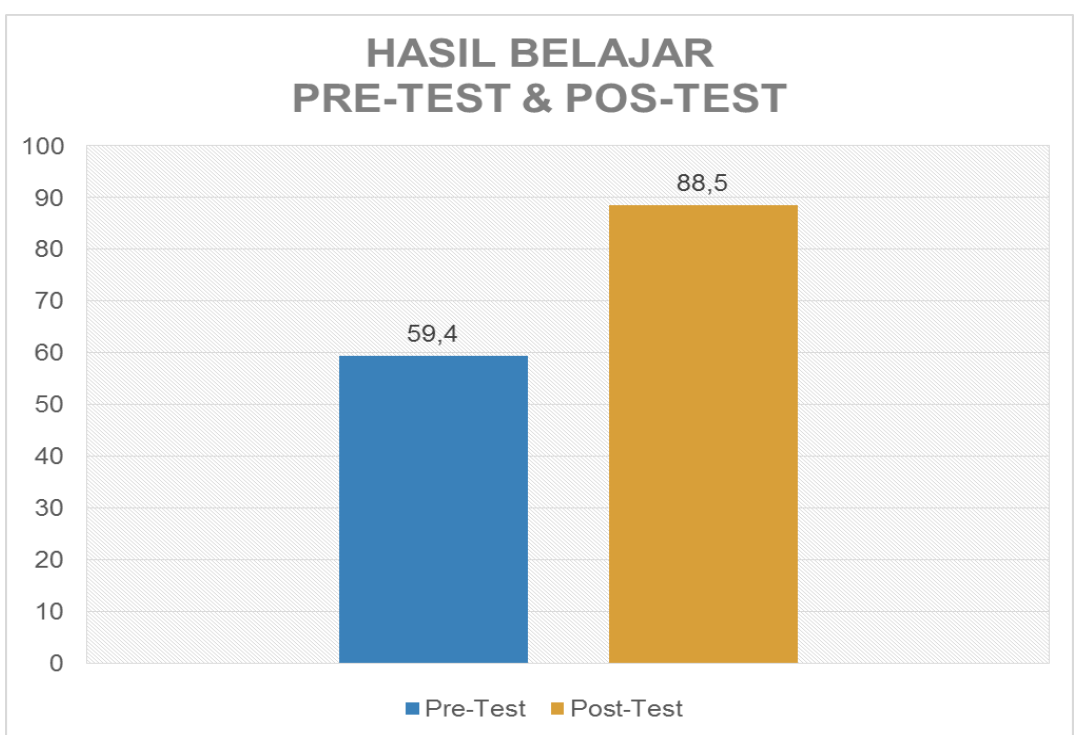

Gambar 5. Hasil belajar pretest dan posttest

Setelah mendapatkan nilai pretest dan nilai posttest, hasil tersebut dianalisis menggunakan uji t dengan taraf signifikan sebesar 0,05. Hasil yang telah dihitung dapat diketahui bahwa hasil sebesar
tTabel $(4,28)$ sedangkan hasil dari tHitung sebesar (2,093). Maka disimpulkan media peta puzzle berbasis adobe flash dengan pendekatan CTL memiliki keefektifan terhadap hasil belajar. 


\section{Simpulan dan Saran}

Hasil pembahasan yang telah diuraikan maka dapat disimpulkan bahwa: (1) Pengemabangan media peta puzzle berbasis adobe flash dengan pendekatan CTL layak digunakan dan diterapkan di kelas IV dalam mata pelajaran IPS tema 8 subtema 1 pembelajaran 4. Hal ini dibuktikan dari hasil validasi yang dilakukan oleh para ahli yang memiliki persentase kelayakan dari ahli media sebesar $86 \%$, kelayakan dari ahli isi materi mendapatkan prosentase $85 \%$ serta angket tanggapan dari guru kelas sebesar 9o\% dan peserta didik sebesar 89\%. (2) Pengembangan media peta puzzle berbasis adobe flash dengan pendekatan CTL efektif digunakan dan dipraktekkan di kelas IV dalam mata pelajaran IPS tema 8 subtema 1 pembelajaran 4. Hasil Penelitian juga dapat dilihat pada nilai pretest sebesar 59 dan nilai posttest sebesar 88 yang mengalami peningkatan secara signifikan. Hal ini juga dibuktikan pada uji-t dimana nilai sebesar tTabel $(4,28)$ lebih besar dibanding tHitung sebesar (2,093). Disimpulkan bahwa hipotesis nol ditolak dan hipotesis alternatif diterima.

Saran yang dapat dibagikan untuk peneliti lain antara lain: (1) Media peta puzzle berbasis adobe flash dengan pendekatan CTL layak diterapkan dan dapat disebarluaskan oleh guru dalam proses pembelajaran. (2) Media peta puzzle berbasis adobe flash dengan pendekatan CTL yang efektif dikembangkan dan digunakan dengan menyesuaikan materi lain sehingga efektif dalam meningkatkan hasil belajar.

\section{Daftar Pustaka}

Andang, Ismail. 2009. Education Games Menjadi Cerdas dan Ceria Dengan Permainan Edukatif. Yogyakarta: Pilar Media

Hariyanto dan Suyono. 2011. Belajar dan Pembelajaran. Bandung: Remaja Rosdakarya

Jamil, Sya'ban. 2012. Games untuk Keluarga, Jakarta: Republika Penerbit

Pranowo, G. 2011. Kreasi Animasi Interaktif Dengan Action Script 3.o pada Adobe Flash $C_{5}$. Yogyakarta: Andi

Sugiyono. 2008. Metode Penelitian Kuantitatif, Kualitatif, dan RED. Bandung: CV Alfabeta . 2012. Metode Penelitian Kuantitatif, Kualitatif, dan RED. Bandung: CV Alfabeta

Suprijono, agus. 2012. Cooperative Learning Teori E Aplikasi Pakem. Yogyakarta Pustaka Pelajar

Susanto, Ahmad. 2013. Teori Belajar dan Pembelajaran di Sekolah Dasar. Jakarta: Kencana 